This is an Accepted Manuscript of an article published by Taylor \& Francis in Journal of Contemporary China on 07 Jul 2019, available online: $\underline{\text { https://doi.org/10.1080/10670564.2019.1637562 }}$

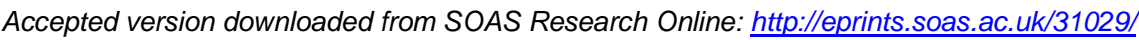

\title{
Party-state Realism: A Framework for Understanding China's Approach to Foreign Policy
}

Steve Tsang ${ }^{1}$

SOAS University of London, UK

\begin{abstract}
The author puts forth an analytical framework called party-state realism for understanding how policy makers in the People's Republic of China approach foreign policy. It has four defining characteristics. In order of importance, they are: putting the interests of the Communist Party at the core of China's national interest calculation; and on this basis adopting an instrumentalist approach; adopting a party-centric nationalism; and adhering to a neoclassical realist assessment of the country's place in the international system and its relative material power in advancing national interest. In this conception, the putting of the Chinese Communist Party's interest at the core of national interest is a constant, not a variable, factor. This does not mean the changing international context and relative national power are irrelevant, just that they take secondary importance.
\end{abstract}

With China emerging as the only other potential superpower and its leader Xi Jinping articulating an ambition for the People's Republic of China (PRC) to take centre stage in global affairs, it is useful to have an analytical framework that sets out the drivers of Chinese foreign policy. ${ }^{2}$ Notwithstanding Xi's rhetoric that China should take centre stage in world affairs and the fact that Chinese power has been on an uninterrupted upward trajectory for over two decades, it remains reluctant, in comparison to other permanent members of the United Nations Security Council, to take on leadership roles in global affairs where Chinese interests are not immediately at stake. Its unusual approach poses a challenge to mainstream international relations theories. While neoclassical realism seems to apply to how the Chinese approach many foreign policy issues, it falls short as changing relative national power and state to state relations are not the primary driver of Chinese foreign policy. Although Alastair Iain Johnston concludes that China is a status quo rather than a revisionist power, such a distinction is ultimately moot. ${ }^{3}$ In reality, Beijing takes 'an à la carte approach to the existing system, supporting those international institutions that serve its interests (...), turning others (...) to its own purposes, and weakening or subverting those (...) that might otherwise pose a challenge to its legitimacy. ${ }^{, 4} \mathrm{~A}$ recognition of the limitations of mainstream international relations theories as applied to China has led to attempts to find alternative explanations to explain China's approach to the rest of the world. Quansheng Zhao opted for

\footnotetext{
${ }^{1}$ steve.tsang@soas.ac.uk

${ }^{2}$ Xi's speech at $19^{\text {th }}$ Congress of Chinese Communist Party, 18 Oct. 2017, http://www.xinhuanet.com/english/download/Xi_Jinping's_report_at_19th_CPC_National_Congress. pdf, p.9 (accessed 29 Jan. 2018).

${ }^{3}$ Alastair Iain Johnston, 'Is China a Status Quo Power?', International Security, 27:4 (2003) pp.5-56.

${ }^{4}$ Aaron L. Friedberg, Competing with China’, Survival 60:3 (2018), pp.24-5.
} 
the micro-macro linkage concept that addresses the interactions between international constraints and domestic determinants at the macro level as well as the approach of decision makers at the micro level. ${ }^{5}$ Conceived two decades ago his analysis was based on experience in the transition from the Mao Zedong to the Deng Xiaoping era. China under Xi has changed considerably since then. Feiling Wang puts forth an interpretation that perceptively identifies three key drivers for Chinese foreign policy, namely 'the CPC's political preservation, China's economic prosperity and more Chinese power and prestige'. ${ }^{6}$ But he does not explain how they relate to the wider literature on international relations. More recently, June Teufel Dreyer has looked astutely at an indigenous concept, the tianxia (all under heaven) trope. ${ }^{7}$ While the worldview of China's leaders definitely reveals significant elements of the tianxia trope, the PRC's foreign policy is driven by forces more powerful than its Sinocentric worldview.

A striking reality that distinguishes China's approach to foreign policy from that of most great powers is the centrality of domestic politics. ${ }^{8}$ Contrary to the pattern in most great powers or the thrust of main international relations theories, which focus on foreign policy considerations, relative capabilities and state to state interaction, consistently the most basic driver of the PRC foreign policy is domestic. The international relations theories that fit this reality best are Innenpolitik theories though on their own they are also insufficient to explain Chinese foreign policy as a whole. In general terms Innenpolitik theories 'argue that internal factors such as political and economic ideology, national character, partisan politics, or socioeconomic structure determine how countries behave toward the world beyond their borders'. ${ }^{9}$

In the case of the PRC its approach is determined first and foremost by its political system. A focus on the system rather than ideology is important as Communism as the state ideology has essentially been put aside in the post-Mao era, particularly after the Tiananmen Massacre (1989) and the collapse of Communism in Eastern Europe. As this author has explained elsewhere the post-Mao system is a 'consultative Leninist' one, which means the 'Communist Party is obsessively focused on staying in power, for which maintaining stability in the country and pre-emptively eliminating threats to its political supremacy are deemed essential'. ${ }^{10}$ This is such an overriding consideration for policy makers in China that it applies as much to foreign policy as it does to domestic policies. As Xi told Chinese diplomats, they must 'uphold the authority of the CPC Central Committee as the overarching

\footnotetext{
${ }^{5}$ Quansheng Zhao, Interpreting Chinese foreign policy: The micro-macro linkage approach (Hong Kong: Oxford University Press, 1996).

${ }^{6}$ Feiling Wang, 'Preservation, Prosperity and Power: what motivates China's foreign policy?’ Journal of Contemporary China 14:45 (2005), p.694.

${ }^{7}$ June Teufel Dreyer, ‘The “Tianxia Trope”: will China change the international system?’, Journal of Contemporary China, 24:96, (2015), pp.1015-31.

${ }^{8}$ Hongyi Lai, The Domestic Sources of China's Foreign Policy: Regimes, Leadership, Priorities and Process (London: Routledge, 2010).

${ }^{9}$ Gideon Rose, 'Neoclassical Realism and Theories of Foreign Policy’, World Politics 51:1 (1998), p.148.

${ }^{10}$ Steve Tsang, 'Consultative Leninism: China’s new political framework', Journal of Contemporary China 18:62 (2009), p.866.
} 
principle and strengthen the centralized, unified leadership of the Party on external work' ${ }^{11}$ This is the point of departure for but not the sum total of Chinese foreign policy making.

Being the core of the 'consultative Leninist' system the Communist Party of China (CPC) is much more than the governing party or the party in power. It in effect claims and takes ownership of the country or the state and it asserts a monopoly in national narrative including how national interest is defined. The system in place is a Leninist party-state as the Party exercises a monopoly of the state and military power to an extent unimaginable in democracies or most authoritarian states. Based on this reality this paper puts forth a new analytical framework called party-state realism for understanding how PRC policy makers approach foreign policy in the post-Mao era. (This analytical framework should also be applicable to other Leninist party-states after the collapse of Communism in Eastern Europe and the Soviet Union.) In this conception, the putting of the CPC's interest at the core of national interest is a constant, not a variable, factor that underpins Beijing's foreign policy making. This does not mean the changing international context is irrelevant, just that it takes secondary importance.

This approach implies that national interest calculation as applied by Chinese policy makers may or may not match a non-partisan evaluation of what would be in China's national interest. Official Chinese foreign policy does not acknowledge that its starting point is the interest of the Party. Instead, it presents foreign policy in terms of promoting Chinese national interest. In the $\mathrm{Xi}$ era, this is posed as a revival of the greatness of China encapsulated in 'the China Dream'. ${ }^{12}$ To understand Beijing's actual foreign policy one should not start with (though not ignore) what opportunities are on offer as a result of changing relative national power. Instead, one should start with what the CPC sees as the most basic - to protecting and enhancing regime security, which includes maintaining stability, upholding national security and sustaining economic growth. Where such an assessment is at variance with the articulated foreign policy, it is regime security that prevails.

\section{Defining Characteristics}

By adapting consultative Leninism to foreign policy making party-state realism serves as an analytical framework for understanding how the Chinese Government in the post-Mao era approaches relations with the outside world. It has four defining characteristics, which are, in order of importance:

- First and foremost, putting the interests in particular the survival of the Communist Party at the core of China's national interest calculation; and on this basis

- Adopting an instrumentalist approach to international organizations, cooperation, law and norm as well as economic ties;

- Adopting a party-centric nationalism that instils in its citizens a belief that the restoration of China's greatness and its rightful place in the world can only be

\footnotetext{
${ }^{11}$ Ministry of Foreign Affairs, 'Xi Jinping Urges Breaking New Ground in Major Country Diplomacy with Chinese Characteristics', 23 June 2018, http://www.fmprc.gov.cn/mfa_eng/wjdt_665385/wshd_665389/t1571296.shtml (accessed 15 Aug. 2018).

${ }^{12}$ Honghua Men \& Steve Tsang, 'Genesis of a Pivotal Decade', in Steve Tsang \& Honghua Men (eds.), China in the Xi Jinping Era (London: Palgrave Macmillan, 2016), pp.2-3.
} 
achieved under the leadership of the Party; ${ }^{13}$ and finally, taking into account these three factors,

- Adhering to a neoclassical realist assessment of the country's place in the international system and its relative material power in advancing national interest.

\section{Party-first national interest}

Even though Xi Jinping is not attempting a Maoist restoration, ${ }^{14}$ he acts as if he were the true heir to the PRC's founding leader, Mao Zedong, as he seeks to reclaim China's place as the most magnificent great power in the world. In the language of the late twentieth and early twenty-first century it means transforming China into a superpower. This is to be achieved by pursuing the China Dream of national rejuvenation, which is to be secured by adhering closely to the leadership of the CPC. ${ }^{15}$ While Xi has abandoned Deng Xiaoping's policy of 'hiding capabilities and bidding for time', he has merely done what is inherent in Deng's approach, which is for China to assert itself when it is ready. This quest is also complementary to the Party's assertion of core national interests, which came into usage in the mid-1990s and gained general currency in the 2000s. ${ }^{16}$ It is reinforced by Xi's instruction to Chinese diplomats that 'they are first and foremost "party cadres". 17

China's core interests are summed up most succinctly by Dai Binguo in 2009 when he was the State Councilor superintending foreign policy. He defined them as 'foremost, preserving China's basic state system and state security; after this, national sovereignty and territorial integrity; and in third place, sustain stable development of the economy and society (第一是维护基本制度和国家安全，其次是国家主权和领土完整，第三是经济社会的持 续稳定发展). ${ }^{18}$ Dai's formulation sets the tone and has been adhered to by other Chinese officials and scholars. Indeed, this was reaffirmed by Yang Jiechi who performs a similar role under Xi. Yang said that as Xi Jinping instructed, 'upholding the leadership of the Chinese Communist Party and socialism with Chinese characteristics is the most basic task in foreign policy'. ${ }^{19}$ Even though Dai was clear in the order of importance, Michael Swaine argues that

\footnotetext{
${ }^{13}$ This and the first feature are essentially the same as two of the defining characteristics for consultative Leninism. Tsang, ‘Consultative Leninism', p.866.

${ }^{14}$ A Maoist restoration implies a commitment to reintroduce totalitarianism and to destroy the Party if necessary in order to lead China to achieve its 'revolutionary goal' as defined by the supreme leader.

$\mathrm{Xi}$ is a Leninist who sees the Party as central to achieving his ambitions for China. Xi freely adopting some Maoist practices - part and parcel of the CPC's heritage - does not amount to a Maoist restoration.

${ }^{15}$ Xinhua, 'Xi urges solidarity for national rejuvenation', in Xinhuanet, http://www.xinhuanet.com/english/2015-05/20/c_134256099.htm (accessed 8 Feb. 2018).

${ }^{16}$ Michael Swaine, 'China's Assertive Behavior Part One: On "Core Interests”', in China Leadership Monitor 34 (2011), pp.3-4. http://carnegieendowment.org/files/CLM34MS_FINAL.pdf (accessed, 9 Feb. 2018).

${ }^{17}$ Kevin Rudd, ‘Xi Jinping’s Vision for Global Governance’, Project Syndicate, 11 July 2018, https://www.project-syndicate.org/commentary/xi-jinping-has-a-coherent-global-vision-by-kevinrudd-2018-07 (accessed, 15 Aug. 2018)

18 ‘首轮中美经济对话: 除上月球外主要问题均已谈及’ (First round of US-China economic dialogues: Every subjects are covered except landing on the moon) 29 July 2009, in www.chinanews.com, http://www.chinanews.com/gn/news/2009/07-29/1794984.shtml (accessed, 9 Feb. 2018).

${ }^{19}$ 杨洁簏 ‘在习近平总书记外交思想指引下不断开创对外工作新局面 (Continuously breaking new grounds in external work under the leadership of the diplomatic thinking of General Secretary Xi
} 
in light of the relative frequency in how all three components were mentioned by Chinese officials and media, it was the second component that was most important. ${ }^{20}$

Swaine's relegation of the protection of the party-state to a lower priority reflects a misunderstanding of the original Chinese text, particularly the term guojia anquan (国家安 全) and the explicit ordering of the priorities - Swaine mistook them for numbered bullet points. This has resulted in a misreading of the Party's intent and Dai's words which, as the rest of this section shows, reflect the reality of Chinese foreign policy. In common with many international relations scholars, Swaine translated guojia anquan into 'national security', a term with clear meaning in the English language that chimes with international relations literature. The correct translation should have been 'state security', implying regime security. If Dai or the Party had intended guojia anquan to mean 'national security', he would have put it with the number two component where it would have fitted in well. Indeed, state or regime security reinforces the first and foremost component, which is about protecting the party-state, essential for the physical security of the leaders and potentially their families. ${ }^{21}$ This is the starting point for the Chinese Government view of its core interests. It is about domestic politics which is not contested by external players, and thus does not require regular reiteration by Chinese leaders and officials. In contrast, national security issues like the sovereignty of Taiwan (and other disputed territories) are highly contested internationally, which accounts for the frequency for Chinese officials to refer to them. Swaine's focus on the frequency and intensity that Taiwan and territorial integrity issues are mentioned thus misses the point. With this key concept of guojia anquan mistranslated, Swaine looked pass Dai's statement which put the first component down as the foremost core interest. Being misunderstood by Swaine does not change the reality of China's definition of core interests, which remains that articulated by Dai - the most basic component is regime security. National security, focusing on the upholding of China's sovereignty and territorial integrity, comes second. Sustaining economic and social stability and growth ranks third. This applies all through the post-Mao era, and remains the case under $\mathrm{Xi}$.

Making this distinction enables us to make sense of the PRC's policy towards the Korean Peninsula, particularly as the North Korean regime under Kim Jong-en created a nuclear and missile crisis despite China's declared policy of no nuclear weapons or war on the peninsula. ${ }^{22}$ In addition, Xi Jinping publicly affirmed at the $19^{\text {th }}$ Party Congress (October 2017) that he would like China to take centre stage in global affairs. Putting them together it is reasonable to extrapolate that it is in China's national interest to find a way to ease tension on the Korean Peninsula and pre-empt escalation into military hostilities. Admittedly, China may not be able to resolve this long-standing thorny issue. But it will earn a place in the centre stage of world affairs if it proactively takes a leadership role in finding a constructive

Jinping), http://www.fmprc.gov.cn/web/zyxw/t1430589.shtml (accessed, 13 Aug. 2018). My translation.

${ }^{20}$ Swaine, 'China’s Assertive Behavior', p.5.

${ }^{21}$ The physical security of top leaders has become an acute issue under Xi who ended the immunity of retired Politburo Standing Committee members against all charges when he violated the postMao convention in bringing down and jailing Zhou Yongkang after Zhou's retirement. The overthrown of the CPC can have potential implications for the physical safety for some of its top leaders. The CPC is very mindful of what happened to Nicolae Ceausescu of Romania.

${ }^{22}$ Xinhua, 'Military means not an option for Korean Peninsular issue: spokesperson', 31 Aug. 2017, http://www.xinhuanet.com/english/2017-08/31/c 136571684.htm (accessed, 21 Feb. 2018). 
way forward. Instead, Beijing chose passive cooperation with United Nations sanctions and, above all, an insistence that the world, in particular the United States of America (USA), should not see China as the key to a solution on the Korean Peninsula, at least until China appeared to be completely side-lined when South Korean President Moon Jae-in secured a breakthrough with the winter Olympics diplomacy of early $2018 .^{23}$ It is noteworthy that China played no active part in bringing this about though its tightening of sanction in 2017 undoubtedly forced Kim's hand. The success of Moon in breaking the ice suggests that there was scope for China to have taken more of a leadership role to get the North Koreans and the Americans to talk. Likewise, there is no evidence that Beijing took any initiative to set up the 2018 Singapore summit between Trump and Kim, in contrast to supporting Kim in preparing for the summit once it had been scheduled.

Why did Beijing choose to avoid taking on a proactive leadership role over Korea, when the changing state to state relations and the relative strength of China's position on the peninsula made it the best placed great power to do so while the Trump Administration's belligerency caused widespread international concern in 2017? This becomes understandable if the party-state realist framework is applied.

In this framework the first and foremost priority for Beijing is not taking centre-stage in global affairs, an articulated goal but not an essential requirement. However the Chinese Government may spin it, resolving the Korean crisis will be seen domestically as working with the Trump Administration, which threatened 'fire and fury' against the Kim regime, a 'fraternal' Leninist state whose survival depended on Chinese support. If the Party should appear domestically as weak vis-à-vis the Trump Administration in undercutting the Kim regime, Xi risks being seen as wobbling over his commitment to do whatever it takes to nib in the bud any challenge to the supremacy of the Party within China. The latter was amongst his first major statements of intent after becoming leader in 2012. In his visit to Guangdong late that year he stressed that under his leadership the Party would not made the mistake of the Communist Party of the Soviet Union, in which no one was 'man enough' to stand up against the betrayal of Mikhail Gorbachev in presiding over the collapse of the Soviet Union. ${ }^{24}$ Since then Xi has consistently reaffirmed a commitment to pre-empt anyone from doubting his determination to sustain the consultative Leninist system.

Indeed, if the PRC acts solely on neoclassical realism it will have taken on a leadership role to try to resolve the Korean crisis. To China as a nation there are no compelling reasons why it must sustain the Kim regime, since it has largely ignored China's concerns as it pursues its own nuclear ambition. Indeed, the Kim regime has not been a better neighbor to China than South Korea, emphatically since 2011 and arguably for a good deal longer, notwithstanding the existence of a mutual defense treaty between China and North Korea. Given the great disparity in power even in a hypothetical scenario of North Korea being taken over by South Korea, Beijing can expect its uncooperative, unreliable and troublesome neighbor to be replaced by a united Korea governed from Seoul, which has been very friendly to China. A newly united Korea preoccupied with integrating the north cannot

\footnotetext{
${ }^{23}$ Kinling Lo, 'US should "do its duty” to resolve North Korea nuclear crisis, China says', South China Morning Post, 15 Sept 2017, http://www.scmp.com/news/china/diplomacydefence/article/2111393/china-says-its-not-key-ending-north-korea-nuclear (accessed, 21 Feb. 2018)

246習近平南巡內部講話 (Speech of Xi Jinping during his Southern tour for internal audience)' 8 March 2013, http://www.open.com.hk/content.php?id=1197\#.WpBORRPFLox (accessed, 22 Feb. 2018)
} 
afford to take on China and can be expected to continue a friendly and cooperative policy towards China. If China had taken a leadership role to bring about such an eventuality it would be in a good position to enhance its interests.

Alleged concern that China as a nation may have over an implosion of North Korea a massive refugee influx and the loss of a buffer state - are grossly exaggerated. The harsh terrain in the China-North Korea borders, the relatively small population on the Korean side of the border region, the Yalu River guarded by the Korean People's Army and the People's Liberation Army on both shores, as well as the prospect of being treated as second class citizens in a much wealthier and human rights respecting united Korea against being at best tolerated as troublemaking refugees in Leninist China should make the risk of a large refugee influx low. This is not to say some Chinese leaders do not want to preempt even a small influx of Korean refugees to an economically degenerating region with a significant Korean minority population, which may pose an unwanted challenge to the Party in the Northeast. Given that the government of a united Korea will inherit the nuclear arsenal of the North while the United States Government will work to remove it from the Peninsula, tension between them will heighten. Furthermore, the USA will have lost the raison d'etre for stationing troops in South Korea. The risk that the new Korean government will allow the USA build new bases in the North while existing ones are underutilized is therefore negligible. ${ }^{25}$ China's national interest, in contrast to that of the Communist Party, does not require China to sustain the Kim regime, though both would prefer stability on the peninsula and the elimination of the risk of any accident involving nuclear devices. ${ }^{26}$

Can Beijing be reticent because its scope to influence North Korea has been significantly reduced since Kim Jong-en came to power in 2011 and purged all Beijingfriendly senior figures from his regime? While this is undoubtedly regrettable to Beijing, it does not change the reality that China still 'provides North Korea with most of its food and energy supplies and accounts for more than 90 percent of North Korea's total trade volume. ${ }^{27}$ This economic leverage is admittedly insufficient to make Kim give up his nuclear program but China does not need to resolve the nuclear crisis to secure a place in center-stage of global affairs. By taking the lead to do so and using its economic leverage will have gone a very long way to achieve this. After all, China gained enormous kudos in the recent past by merely hosting the non-conclusive six-party talks. There is much that Beijing can gain in its standing in the world by taking a constructive leadership role in seeking a solution. This is an option dismissed because ultimately the

\footnotetext{
${ }^{25}$ The USA has 15 bases in South Korea, of which two are operated by the Air Force and one by the Navy. Of the two Air Force bases, only Osan is home to a combat air wing. With the Kunshan base heavily under-utilized and capable of hosting another air wing, it is hard to see the USAF demanding (and a united Korean government accepting) a new base in northern Korea. President Trump in fact articulated a willingness to withdraw US forces from Korea after he met Kim in Singapore in June 2018. Josh Smith \& Phil Stewart, 'Trump surprises with pledge to end military exercises in South Korea’, 12 June 2018, Reuters, https://uk.reuters.com/article/uk-northkorea-usa-military/trumpsurprises-with-pledge-to-end-military-exercises-in-south-korea-idUKKBN1J816N (accessed, 15 June 2018).

${ }^{26}$ Ironically, the risk of an accident involving a nuclear device on the Peninsular is more likely to be reduced with a united Korean with no nuclear weapons than a North Korea armed with nuclear weapons.

${ }^{27}$ Eleanor Albert, ‘The China-North Korea Relationship', https://www.cfr.org/backgrounder/chinanorth-korea-relationship (accessed, 21 Feb. 2018)
} 
Chinese leadership is, for regime security reasons, unwilling to show a lack of determination to sustain its vexatious Leninist 'little brother'.

China's approach towards the Korean peninsula is not an aberration. The same basic consideration determines how its government tackles foreign policy generally. Xi might have spoken as if China were ready to take a leadership role in economic globalization at Davos (2017) when the Trump Administration advocated 'America first'. ${ }^{28}$ But his government did not really follow up on such a grandiose gesture. The Chinese Government talks about global common good but acts on Party interests. This attitude is also reflected powerfully in China's support for authoritarian regimes globally.

There is no reason to believe that supporting any type of political system, be it democratic or authoritarian is inherently in the national interest of China, in contrast to that of the Party. The experience of Taiwan, Hong Kong and Mainland China show that Chinese people can flourish in a democracy, a hybrid system or a Leninist party-state. The PRC also maintains good and mutually beneficial relations with countries across regime types. The better relationship Beijing has with Seoul than with Pyongyang underlines the irrelevance of regime type. Likewise, authoritarian Vietnam does not maintain friendlier relations with the PRC than democratic Indonesia within Southeast Asia.

But Chinese foreign policy is geared to support authoritarian states, even though it is not official Chinese policy to export the consultative Leninist model. ${ }^{29}$ The official position, in the language of Xinhua, is that 'the CPC is willing to share its vision, path and experience'. ${ }^{30}$ Technically, the policy is not to proactively export the Chinese political system but to assist any government which seeks to learn from its authoritarian development model. Beijing also seeks to ensure its approach to governance in the Internet and other areas prevails globally. But the crux of the matter is to stem the tide of change unleashed by the advent of color revolutions at the end of the Cold War. Supporting authoritarian states makes the CPC less vulnerable to any Western 'conspiracy' inherent in the idea of a 'peaceful evolution' ${ }^{31}$

In an important sense this Chinese approach both contrasts against and parallels the American commitment to aid democracy abroad. Successive US administrations since President Woodrow Wilson have steadily incorporated this principle into the body politics of US foreign policy - at least until Donald Trump became President. ${ }^{32}$ Wilson started the

${ }^{28}$ CGTN, 'Full Text of Xi Jinping keynote at the World Economic Forum’ 17 Jan. 2017, https://america.cgtn.com/2017/01/17/full-text-of-xi-jinping-keynote-at-the-world-economic-forum (accessed, 20 Aug 2018).

${ }^{29}$ Reuters, 'President Xi says China will not export its political system’ 1 Dec. 2017, https://www.reuters.com/article/us-china-parties/president-xi-says-china-will-not-export-its-politicalsystem-idUSKBN1DV4UM (accessed, 23 March 2018).

${ }^{30}$ Xinhua, 'Commentary: China willing to share, but not to export Chinese model’ 4 Dec. 2017 http://www.xinhuanet.com/english/2017-12/04/c 136800287.htm (accessed 23 March 2018).

${ }^{31}$ For Chinese concern about peaceful evolution, see Russell Ong, “"Peaceful Evolution”, "Regime C hange” and China's Political Security', Journal of Contemporary China 16:5 (2007), pp.717-727. The CPC leadership is convinced that the West led by the USA is committed to secure the collapse of the party-state. 李慎明, 中国和平发展与国际战略(China's Peaceful Development and International Strategy) (Beijing: Zhongguo Shehui kexue chubanshe, 2007), p.30.

32 Thomas Carothers, Aiding Democracy Abroad: The Learning Curve (Washington: Brookings Institution Press, 1999). 
process to 'make the world safe for democracy', a sentiment shared by most Americans. It is true that some national leaders in other political systems, for example Nicholas Maduro of Venezuela, prioritizes personal interest above wider national interest. Arguably even Trump does it in the USA, a long-established democracy. But an individual leader pursuing personal interest above national ones is not the same as a political system invariably putting sustaining the Party's monopoly of power above the state and national interest. In China its leader systematically acts on the Party's behalf to make the world safe for authoritarian states. By issuing Document 9 of 2013, Xi has made it clear the Party must resolutely oppose and eliminate any effort to promote 'western' concepts like constitutional democracy or universal values. ${ }^{33}$ With sustaining the Party's rule being the starting point of China's national interest, the PRC consistently supports authoritarian states to survive, develop and flourish - as an antidote to post-Cold War color revolutions in recent decades.

\section{Instrumentalist in cooperation or confrontation}

The Chinese Government regularly underlines the importance of basic principles, such as non-interventionism, projecting an image that it is a principled actor in international affairs. Its proclivity to take a moralistic stance reflects the domestic political reality that as a party-state it enjoys a monopoly of 'the truth' and narrative at home and its policies are always right. But, in reality, it engages with the rest of the world on calculation of interests. Indeed, pragmatism inherent in neoclassical realism modified by party-first national interests means that the Chinese Government's basic approach to cooperation or confrontation is instrumentalist, which is in general terms the second most important defining feature of party-state realism.

This is reflected most clearly in how Beijing views and deals with the international order centered on the United Nations and its ancillary institutions. International organizations or institutions are valued or dismissed depending on how useful they are to Beijing but Chinese rhetoric always presents its approach as based on high-sounding principles. In reality where the international order does not work to the interest of the partystate, the Chinese Government dismisses it or seeks to change it but where it does, it upholds the order. This instrumentalist approach renders efforts to categorize China a status quo or revisionist power moot.

Before the PRC was widely embraced as a near superpower and was able to assert itself strongly, it was highly defensive about the international human rights regime in light of domestic abuse of rights. It largely dismisses this regime as part of the post-war US-centric world order that allowed the West to intervene into the domestic affairs of poorer countries. As it does so it deliberately ignores the history that China actually played a key role in creating this regime. Chinese diplomat P.C. Chang (Zhang Pengchun) served as one of the first vice-chairmen of the Commission on Human Rights and was 'one of the most active and influential participants in the writing of the Universal Declaration of Human Rights'(UDHR). ${ }^{34}$ Indeed, Chang made his 'most important contribution' in his 'strong commitment to the universality of the UDHR' ${ }^{35}$

\footnotetext{
33 'Document 9: A ChinaFile Translation', 8 Nov. 2013, http://www.chinafile.com/document-9chinafile-translation (accessed, 28 Aug. 2018).

${ }^{34}$ Frédéric Krumbein, 'P. C. Chang-The Chinese Father of Human Rights', Journal of Human Rights (2015), 14:3, 332. The claim that Chang did not represent China as he was not appointed by the Communist Party is highly problematic, as Chang was the official representative of China.

${ }^{35}$ Krumbein, 'P. C. Chang', p.337.
} 
When the UN regime on human rights was to be revamped in the 2000s Beijing saw a threat and an opportunity. It neutralized the threat by seizing the opportunity. It 'engaged heavily in the institution-building negotiations' and secured a seat at the new Human Rights Council to limit criticism against it. ${ }^{36} \mathrm{~A}$ decade since the Council was established and as China takes a more assertive approach under $\mathrm{Xi}$, it strives to make the Council align closer to its interests. It seeks 'to block or weaken UN resolutions on civil society, human rights defenders and peaceful protests' as well as pushing back against efforts to strengthen some of the mechanisms for country-specific rights advancement. ${ }^{37}$ Consequently, the Human Rights Council is no longer a regular thorn on China's side even though the detention of about one in ten of the entire Uyghur population in camps (officially called 'vocational training centers') in Xinjiang means the abuse of rights in China has reached a level unprecedented since the Beijing Massacre of $1989 .{ }^{38}$ The same international institution to which Beijing took exception when it put pressure on human rights in China has now been neutralized. ${ }^{39}$ Indeed, Beijing's instrumentalist approach has transformed this important UN agency from being a 'hostile' organization into a 'friendly' one.

At the core of the UN itself, China enjoys its status as a permanent member of the Security Council, which carries the obligation to share the 'responsibility for the maintenance of international peace and security', in accordance with Article 24 of the Charter. ${ }^{40}$ Unlike the USA, Britain or France, which regularly take on a lead role on difficult peace and security issues China prefers to stay in the backseat. ${ }^{41}$ China also conducts itself differently from Russia as it, on balance, does 'not opt for obstructive behavior in the S[ecurity] C[ouncil]' either. ${ }^{42}$ It is important not to confuse supporting peace-keeping with taking a leadership role in maintaining international peace and security.

In peace keeping operations China provides more troops than any other permanent member of the Security Council. But then 'developing states ... typically compose the top ten

\footnotetext{
${ }^{36}$ Sonya Sceats \& Shaun Breslin, China and the International Human Rights System (London: Chatham House, 2012), pp.10-15.

${ }^{37}$ Human Rights Watch, 'The Costs of International Advocacy', 23 May 2017, https://www.hrw.org/report/2017/09/05/costs-international-advocacy/chinas-interference-unitednations-human-rights (accessed, 31 May 2018).

${ }^{38}$ This systematic abuse of rights of an identifiable minority of Chinese citizens and the Chinese Government's commitment to make the world safe for authoritarianism raises the question whether they will determine how Beijing sees relations with its neighbours and other states. For the camps, see Adrian Zenz, “"Thoroughly reforming them towards a healthy heart attitude”: China's political reeducation campaign in Xinjiang', Central Asian Survey (2019), 38:1, pp.102-28.

${ }^{39}$ Dave Lawler, 'China's growing influence swallows global criticism on human rights', 9 Nov. 2018, https://www.axios.com/chinas-influence-global-criticism-human-rights-9bea0780-90a6-4f65-88994aa5ebf714d0.html (accessed, 9 Nov. 2018).
}

\footnotetext{
${ }^{40}$ United Nations, 'UN Charter', http://www.un.org/en/sections/un-charter/un-charter-full-text/ (accessed, 1 June 2018).

${ }^{41}$ Sally Morphet, 'China as a Permanent Member of the Security Council October 1971-December 1999’, Security Dialogue, 31:2 (2000), pp.151-166.

${ }^{42}$ Suzanne Xiao Yang, China in UN Security Council Decision-making on Iraq (London \& New York: Routledge, 2013), 100.
} 
troop contributors. ${ }^{43}$ Indeed, UN peace-keeping operations historically did not usually involve troops from the permanent members of the Security Council in order to avoid them dominating such operations. What is noteworthy about the Chinese approach to peacekeeping is how pragmatic it has been in reversing its previous refusal to support it. As it seeks to project a new identity of being 'simultaneously a great power and a Global South member’ it proactively provides funding and troops to support peace-keeping operations. ${ }^{44}$

China remains reticent in taking a leadership role on international peace and security generally, and even in its neighborhood. As explained, it has consistently refused to play a more proactive part than hosting the six-party talks (2003-8) over the Korean Peninsula, a significant but essentially passive role.

As a permanent Security Council member China is keener to keep the existing membership and structure unchanged even though it officially supports 'increasing the representation of developing countries' to counter the West's disproportionate dominance. ${ }^{45}$ China advocates keeping the Security Council unchanged in order to ensure that Japan cannot gain a permanent seat. ${ }^{46}$ It upholds the existing international system as it 'basically serves the interests of China'. ${ }^{47}$

\section{Party-centric nationalism}

A 'consultative Leninist' system requires a party-directed belief system to give it ideological cohesion in order to operate effectively. When Communism ceased to function as the state ideology after the Beijing Massacre of 1989, the Party adopted nationalism to fill the void, even though it continued to espouse Communism as the official ideology. Strictly speaking nationalism is not a proper ideology like Communism. It was chosen because it was 'the most reliable claim to the Chinese people's loyalty and the only important value shared by the regime and its critics. ${ }^{48}$ It enabled the Party 'to position themselves as the defenders of China's national pride' and unity. ${ }^{49}$ In this sense it gives an ideological cohesion to the party-state. Since then the party-state has effectively instilled in PRC citizens the 'my country right or wrong' brand of nationalism. But this also imposes a requirement that any Chinese foreign policy must pass a patriotic test, which generally entails the government not appearing weak under pressure vis-à-vis its international interlocutors. This is the third defining feature of party-state realism.

As Xi makes 'the China Dream' a center piece of Chinese nationalism it takes on an increasingly assertive tone. It is now about 'making China great again'. This passed a

\footnotetext{
${ }^{43}$ Courtney J. Fung, 'What explains China's deployment to UN peacekeeping operations?' International Relations of the Asia-Pacific, 16:3 (2016), p.415.

${ }^{44}$ Ibid, 429. Such operations also enabled Chinese forces to practise deployment overseas.

45 'Position Paper of the People's Republic of China on the United Nations Reforms' 7 June 2005, paragraph IV.3, http://www.china-un.org/eng/chinaandun/zzhgg/t199101.htm (accessed, 11 June 2018).

46 'Position Paper Clarifies China's Stance on UN Security Council Reform', http://www.china.org.cn/english/international/131439.htm (accessed, 15 June 2018). 47门洪华,构建中国大战略的框架 (Constructing a Framework for a Grand Strategy for China) (Beijing: Peking University Press, 2005), p.260.

${ }^{48}$ Zhao Suisheng, 'China's Pragmatic Nationalism: Is It Manageable?’ The Washington Quarterly, 29:1 (Winter 2005-6), p.134.

${ }^{49}$ Ibid.
} 
significant landmark in the $19^{\text {th }}$ Party Congress (October 2017) when Xi put an end to internal debates on whether China's moment had come. He ended the Dengist strategy of 'hiding capabilities and bidding for one's time' and proclaimed a new era in which China expects to take center stage in global affairs. ${ }^{50} \mathrm{Xi}$ has increased the relative weight of nationalism as a defining feature of party-state realism and transformed it into the second most important factor. ${ }^{51}$

At the $19^{\text {th }}$ Congress, $\mathrm{Xi}$ also reaffirmed: 'As history has shown and will continue to bear witness to, without the leadership of the Communist Party of China, national rejuvenation would be just wishful thinking. ${ }^{52}$ Under Xi's stewardship, Chinese nationalism is undergoing a further modification - my country right or wrong now implies my party right or wrong, even my leader right or wrong. Criticizing the Communist Party or Xi's leadership is now deemed unpatriotic if articulated by a Chinese and considered unfriendly if made by a foreigner or foreign government. ${ }^{53}$ This imposes an element of ideological rigidity and thus reduces Chinese foreign policy's scope to take full advantage of the constantly changing international scene.

The implication of this new approach is that cold instrumentalism is increasingly required to make way for the more emotional urge to insist on China and its leadership being duly respected. To be sure, this process started even before Xi became leader. Towards the end of Hu Jintao's tenure, after the West's post-Cold War triumphalism was revealed as hubris when the global financial crisis hit, Hu's hallmark instrumentalist policy of stressing China's rise would be peaceful had begun to be eroded. When Hilary Clinton challenged China's salami approach to claim the South China Sea as its newest core interest in 2010 (about which more later), Chinese Foreign Minister Yang Jiechi pushed back. As Yang accused the USA of plotting against China he also threatened Singapore. He said 'China is a big country and other countries are small countries, and that's just a fact', reportedly 'staring directly at Singapore's foreign minister' as he did so. ${ }^{54}$ This was unnecessary, counterproductive and not in accord with the instrumentalist approach. It is noteworthy that there is no evidence that Yang did so under Hu's order.

This drift towards emotion driven assertiveness became mainstream after Xi took over from Hu. Yang's successor as Foreign Minister Wang Yi surpassed Yang by publicly lambasting a Canadian journalist during an official visit to Ottawa in 2016. When the Canadian reporter questioned him about China's human rights record, Wang retorted: 'This is totally unacceptable. Have you ever been to China? Please do not ask questions in such an

\footnotetext{
${ }^{50}$ Xi's speech at $19^{\text {th }}$ Congress of Chinese Communist Party, 18 October 2017, http://www.xinhuanet.com/english/download/Xi Jinping's report at 19th CPC National Congress. pdf, 9 (accessed 13 Aug 2018).

${ }^{51}$ Party-centric nationalism has not been put as the second defining feature for this analytical framework even though most of the time it is the case under Xi because the framework applies to the post-Mao period as a whole, not only to the Xi era.

52 Xi's speech at $19^{\text {th }}$ Congress of Chinese Communist Party, (accessed 13 Aug 2018).

${ }^{53}$ This is not to claim that Xi has completely ended all form of criticism or dissent within China. Xi is restoring a very hard form of authoritarianism that utilises smart technologies, not totalitarianism.

${ }^{54}$ John Pomfret, 'U.S. takes a tougher tone with China' Washington Post, 30 July 2010,

http://www.washingtonpost.com/wpdyn/content/article/2010/07/29/AR2010072906416.html??noredirect $=$ on\&sid=ST2010072906761
} (accessed, 13 Aug. 2018). 
irresponsible manner. ${ }^{55}$ Likewise, when Australian Prime Minister Malcolm Turnbull articulated concern over foreign powers 'making unprecedented and increasingly sophisticated attempts to influence the political process' in Australia in late 2017 the Chinese Foreign Ministry spokesman countered in public: 'We are astounded by the relevant remarks of the Australian leader. Such remarks simply cater to the irresponsible reports by some Australian media that are without principle and full of bias against China. ${ }^{56}$ Neither the Canadian reporter nor the Australian Prime Minister was hostile to China though they questioned the record of the Communist Party in human rights or in infiltrating Australian society and politics. While they reflected discomfort, it was the forceful Chinese responses that caused real concern.

This assertiveness driven by party-centric nationalism further undermines a specific objective of Chinese foreign policy - the cultivation of soft power. Indeed, what the Chinese Government has in reality managed to project, more intensely under Xi than previously, is not soft power but what Christopher Walker and Jessica Ludwig have described as 'sharp power'. Sharp 'in the sense that they pierce, penetrate, or perforate the political and information environments in the targeted countries', which seek 'to manipulate their target audiences by distorting the information that reaches them' ${ }^{57}$ Unlike Russia, which has little choice but to resort to sharp power to make itself relevant globally, China's stunning achievements in the last decade have given it scope for real soft power. As symbols of capitalism like the Lehman Brothers collapsed and Western democracies careened into crisis China's 'consultative Leninist' model looked impressive as it emerged from the global financial crisis. In the Xi era, China is home to world class companies like Alibaba and Tencent and a leader in cutting edge technologies such as artificial intelligence. It now has tremendous scope to generate international admiration without resorting to sharp power. However, party-centric nationalism directs the Xi Administration to project 'soft power' through Confucius Institutes and the Belt and Road Initiative and, in so doing, confuses sharp power with soft power. ${ }^{58}$

\section{Neoclassical realism at work}

With the Party's interest as the starting point of national interest, neo-classical realism provides a useful guide for understanding China's foreign policy calculation. For this to work well one also needs to factor in the instrumentalist 'magic weapon' of the United Front and party-centric nationalism.

\footnotetext{
${ }^{55}$ Derek Burney \& Fen Hampson, 'When China feels superior, so does its envoys', The Globe and Mail, 6 June 2016, https://www.theglobeandmail.com/opinion/when-china-feels-superior-so-do-itsenvoys/article30277083/ (accessed, 13 Aug. 2018).

${ }^{56}$ Bill Birtles, 'China lodges official complaint after Malcolm Turnbull's comments about foreign interference', ABC News, 9 Dec. 2017, http://www.abc.net.au/news/2017-12-09/china-lodges-official-complaint-after-tumbullscomments/9242630 (accessed, 14 Aug. 2018).

${ }^{57}$ Christopher Walker \& Jessica Ludwig, 'The Meaning of Sharp Power: How Authoritarian States Project Influence’, Foreign Affairs, 16 Nov. 2017, https://www.foreignaffairs.com/articles/china/2017-11-16/meaning-sharp-power (accessed, 14 Aug. 2018).

${ }^{58}$ Elizabeth C. Economy, The Third Revolution: Xi Jinping and the New Chinese State (Oxford: Oxford University Press, 2018), pp.219-24.
} 
The United Front concept was originally introduced by Vladimir Lenin but Mao modified it to make it much more potent. As the CPC still has a United Front Department, it is easy to assume that the United Front is about the work of this shadowy unit, of which the overwhelming majority of its 12 sub-departments are domestically focused. To do so will miss another, more important, side to the United Front. Mao would not have described it as one of the three 'magic weapons' if he did not think this was highly effective. ${ }^{59}$ The United Front needs to be understood as a methodology which the Party uses to guide foreign policy as it does domestic struggles.

The United Front is about ensuring the CPC will come out on top in any contest. Its starting point is to distinguish enemies from friends and treat them in ways to cripple enemies step by step. ${ }^{60}$ 'In the simplest terms, the United Front requires the Party to identify a principal enemy, its supporters, and the intermediate zone full of "wavering elements" that can be won over by either the Party or its principal enemy.' 61 The Party is required to exercise strong discipline to focus its attack on the principal enemy and win over, or at least neutralize, as many as possible in the intermediate zone. The Party has no illusion that alliances thus forged would be temporary. They are meant to isolate and thus weaken the principal enemy. Once the principal enemy has been destroyed, the Party elevates one from among the secondary enemies in the intermediate zone to new principal enemy status. It now becomes the focus of attack until it too is defeated. The Party is supposed to repeat the process until no enemy is left and those in the intermediate zone are all converted to 'friends'. ${ }^{62}$

By harnessing this to foreign policy the Chinese Government takes a hardnosed approach to assess relative strength between itself and its interlocutors, on the basis of 'comprehensive national strength' as well as the relative capacity to make the international environment conducive to its interests. ${ }^{63}$ As Anne-Marie Brady rightly observes, the Party takes to heart Lord Palmerston's famous adage - 'there are no permanent friends, only permanent interests. ${ }^{64}$ Embedding the United Front approach 'requires Chinese foreign policy makers to stay focused on one primary enemy at any one time.' ${ }^{65}$ As they do so they calculate relative strength as well as costs and benefits ruthlessly but this does not imply they always understand the others or the context astutely or maintain the discipline required to secure the desired results. Indeed, party-centric nationalism and/or over-confidence based on nouveau rich hubris can distort or weaken adherence to the United Front methodology.

\footnotetext{
${ }^{59}$ The other two magic weapons were party building and armed struggle. Mao Zedong, 毛泽东选集 (Selected Works of Mao Zedong), vol. 2 (Beijing, Renmin chuban she, 1970), p.569.

${ }^{60}$ The classic on the subject remains Lyman P Van Slyke, Enemies and Friends: The United Front in Chinese Communist History (Stanford: Stanford University Press, 1968).

${ }^{61}$ Steve Tsang, 'China's Grand Strategy and its Rise', in Bo Huldt, Mika Kerttunen, Bo Wallander, Masako Ikegami \& Susanna Huldt (eds.), China Rising: Reactions, Assessments, and Strategic Consequences (Stockholm: The Swedish National Defence College, 2007), p.52.

${ }^{62}$ Zhonggong zhongyang wenxian yanjiushi (comp.), Mao Zedong Wenji 毛泽东文集 vol.4 (Beijing, Renmin zhubanshe, 1998), 196-200要胜利就要搞子统－战线(To secure victory one must get it right with the United Front); \& Liao Gailong, 毛泽东思想史(A History of Mao Zedong Thought) (Hong Kong: Zhonghua Shuju, 1993), pp.187-214.

${ }^{63}$ For an exposition of 'comprehensive national strength' see Angang Hu \& Honghua Men, 'The Rising [sic] of Modern China: Comprehensive National Power and Grand Strategy' (2002), https://myweb.rollins.edu/tlairson/china/chigrandstrategy.pdf (accessed, 30 May 2018).

${ }^{64}$ Anne-Marie Brady, Making the Foreign Serve China (Latham: Rowan \& Littlefield, 2003), p.21.

${ }^{65}$ Tsang, 'China’s Grand Strategy and its Rise', p.52.
} 
This approach is exemplified in how China handles the maritime disputes in South China Sea. While its government laid claim based on a map drawn up by its predecessor government dating back to 1947, it issued 'no legal document ... which formally recognizes the legal status of the nine-dashed line' map. ${ }^{66}$ As China's standing in East Asia and its 'comprehensive national strength' reached a new height in 2010, the Chinese authorities allowed or encouraged retired senior officers and affiliates to its national defense educational establishment to put forth the idea that South China Sea and the reefs and rocks China claims should be treated as a kind of proto core interest. ${ }^{67}$ If such statements went unchallenged the Chinese would be able to generate incrementally a 'conventional wisdom' that South China Sea should be deemed their core national interest. According to Hilary Clinton Chinese State Councilor Dai Bingguo mentioned (presumably in private as no public statement can be found) South China Sea as a core interest at the US-China Strategic and Economic Dialogue in May 2010 about which she contested. ${ }^{68}$ Clinton's account has been questioned by Michael Swaine who concludes that 'Beijing has not unambiguously identified the South China Sea issue as one of its core interests' and if Clinton's recollection was correct, it 'was done in a decidedly unofficial manner' ${ }^{69}$ Swaine's latter assessment is likely to be on the mark. Up to the end of Hu Jintao's term of office (2012) Beijing had been very careful in not allowing any senior official or active service senior officer articulate such a claim formally or publicly, which would have put South China Sea on par with Taiwan or Tibet. ${ }^{70}$

A major development did take place in the summer of 2010, when Clinton, as American Secretary of State, for the first time publicly challenged the salami-slicing approach of the PRC in seeking to change international perception of South China Sea. International recognition that Beijing would use force to defend its core interest gives significance to such Chinese efforts. Clinton put Beijing on the spot by declaring at the July ASEAN Regional Forum meeting that 'The United States has a national interest in freedom of navigation, open access to Asia's maritime commons and respect for international law in the South China Sea'. ${ }^{71}$ The Chinese Government pulled back and the demi-official assertion of the South China Sea as proto core interest ceased. When Premier Wen Jiabao next reiterated China's commitment to defend its core interests in a speech to the United Nations the following month, it was conspicuous by its absence. ${ }^{72}$

\footnotetext{
${ }^{66}$ Zheng Wang, 'Chinese Discourse on the "Nine-Dashed Line”', Asian Survey 55:3 (2015), 504-8.

${ }^{67}$ Willy Lam, 'Hawks vs Doves: Beijing Debates “Core Interests” and Sino-U.S. Relations' China Brief X:17 (19 Aug. 2010), https://jamestown.org/wpcontent/uploads/2010/08/cb_010_86.pdf?x87069 (accessed 30 May 2018). Retired senior military officers and professors in the National Defence University are subject to party discipline and can be reined in by the Party.

${ }^{68}$ US Department of State, 'Interview with Greg Sheridan of the Australian', 8 Nov. 2010, https://2009-2017.state.gov/secretary/20092013clinton/rm/2010/11/150671.htm (accessed, 24 May 2018).

${ }^{69}$ Swaine, ‘China’s Assertive Behavior Part One’, p.9.

${ }^{70}$ Alastair Iain Johnston, 'How New and Assertive is China's New Assertiveness?' International Security 34:7 (Spring 2013), pp.17-18.

${ }^{71}$ Mark Landler 'Offering to Aid Talks, U.S. Challenges China on Disputed Islands', The New York Times, 23 July 2010, https://www.nytimes.com/2010/07/24/world/asia/24diplo.html (accessed 24 May 2018).

${ }^{72}$ Ministry of Foreign Affairs, 'Wen Jiabao Attends the $65^{\text {th }}$ General Debate of the General Assembly and Delivers a Speech', 24 Sept 2010, http://www.fmprc.gov.cn/mfa_eng/topics_665678/wenjibaochuxi65jieUNdh_665784/t755848.shtml (accessed, 24 May 2018).
} 
But Beijing did not give up. It changed tack. After Xi became leader China built artificial islands out of reefs and rocks in the Spratly group and put military installations on them notwithstanding Xi's public pledge not to militarize them. ${ }^{73}$ Creating new realities on the ground that cannot be reversed without the use of force has replaced the previous approach of getting de facto acknowledgement of China's claim. A realistic calculation was made that no Southeast Asian disputant has the capacity and the USA cannot find a legitimate basis and secure international support to reverse its island building.

By embedding the United Front concept, the Chinese approach to foreign policy is governed by a careful calculation of both 'comprehensive national strength' and its ability to win friends and isolate its principal enemy at any one time. This is essentially a realist conception as China seeks to maximize its advantage and push its interests as far as it can go, but it retreats tactically when it meets resistance backed by forces more powerful than what it can muster. But this can be and has under Xi increasingly been distorted where party-centric nationalism is allowed to take precedent.

\section{Conclusions}

The defining features of party-state realism consist of two types. The first and foremost feature, systematically putting the Party first, is a constant factor which is the starting point for Chinese foreign policy making. The 'consultative Leninist' system in place is based on the collective leadership at the top but it is a system that can accommodate the rise of a strongman. Since the $19^{\text {th }}$ Party Congress (2017) collective leadership has in effect been replaced by leadership of the core leader, Xi. In such a context, 'Party first' sometimes means 'core leader first', and party directives on foreign policy, as with all policies, now need to dovetail ' $\mathrm{Xi}$ Jinping Thought for socialism with Chinese characteristics in a new era'. But the basic political system has not changed, and notwithstanding the concentration of power in Xi's hands China remains a party-state. What distinguishes China's approach is that this is driven by the political system and not the personal whims of its leader who occasionally puts personal interest ahead of national interest, which can happen in any political system. The party-state realism framework applies whether the Party is dominated by a core leader or a collective leadership. What remains essential to understanding Chinese foreign policy is to know what the Party sees as a threat to its monopoly of power in China at any one time.

This basic feature determines how Chinese national interests are defined and distorts how international relations theories can apply in the case of China. It takes precedent over all standard foreign policy considerations of a great power and compels the Chinese government not to pursue policies likely to undermine the capacity of the Party to stay in power. In practical terms, it leads to a policy to make the world safe for authoritarianism and to reject humanitarian interventionism. ${ }^{74}$ It also injects an element of pragmatism in external economic relations since the long-term security of the party-state necessitates the

\footnotetext{
${ }^{73}$ David Brunstrome \& Michael Martina, 'Xi denies China turning artificial islands into military bases’, Reuters, 25 Sept 2015, https://www.reuters.com/article/us-usa-china-pacific/xi-denies-chinaturning-artificial-islands-into-military-bases-idUSKCNORP1ZH20150925 (accessed 12 March 2019).

${ }^{74}$ This undoubtedly is what underpins the concern articulated by George Soros at Davos in January 2019 that China under Xi had become 'the most dangerous opponent of open societies'. Joe Miller, 'China's Xi Jinping “most dangerous” to open societies, says George Soros', 24 Jan. 2019, https://www.bbc.co.uk/news/business-46996116 (accessed 8 March 2019).
} 
maintenance of a robust economy and steady growth. Should economic pragmatism conflict with short-term requirements of the security of the regime, however, it is the latter that prevails. Hence, the signature external policy of Xi, the Belt and Road Initiative (BRI), will remain a flagship policy as long as he stays as core leader, whether it proves to be economically beneficial to China or not. The same thinking also restrains China from taking full advantage of the US withdrawal from the Trans Pacific Partnership (TPP). Given the size of the Chinese economy membership would ensure Chinese domination of TPP, a development that could make the BRI appear like a sideshow and thus highly beneficial to China. Likewise, while broadly defined Chinese national interest should need its government to seek to defuse the 'trade war' with the Trump Administration, this can only happen on the proviso that Xi will not appear to bow under American pressure and, above all, that this would not require changes that can undermine the consultative Leninist system.

The interplay and relative significance of the second and third defining features instrumentalism and party-centric nationalism - is a dynamic one. They may not always complement each other but they are not inherently mutually exclusive. Chinese foreign policy under Jiang Zemin and Hu Jintao demonstrated how the two worked complementarily under collective leadership. In this period, internal debates and discussions on policies took place on a routine basis, which had the effect of reducing policy swings in favor of one or the other. With the Dengist principle of hiding capabilities and bidding for time prevailing, party-centric nationalism merely required foreign policy makers to focus on steering China to rise without overtly provoking pushbacks from others. Before Xi established himself as paramount leader and put priority on making China great again, instrumentalism was the second defining feature of party-state realism.

By prioritizing the 'dignity of China' (and its leader) after Xi's rise to dominance the relative significance of the second and third defining feature by and large changed place. Beijing now places greater emphasis on party-centric nationalism than on instrumentalism. This should not be seen as a permanent shift, as Xi can reverse them. Indeed, in many cases, the two features still complement each other. The transformation of the Asian Infrastructure and Investment Bank (AIIB) from a 'China dominated agency' and 'a blatant agent of Chinese foreign policy' into a respected international development bank reflects instrumentalism at its best - Beijing changed when it realized such changes would enable the AIIB to gain wide international support and participation to secure the coveted credibility. ${ }^{75}$ Where the 'dignity of China' is not at stake instrumentalism remains the second defining feature even in the Xi era.

As to the last defining feature, the applicability of neo-classical realism, this works once the peculiarity of the other defining features have been taken into account. It is a 'defining' feature not in the sense that this is new but that this is the international relations theory that applies the most. Starting from the party-first principle neo-classical realism explains Chinese foreign policy, though adjustments need to be made to factor in the relative importance of instrumentalism and party-centric nationalism at any one time. When not put in a party-centric nationalist straightjacket Chinese foreign policy makers are hardnosed realists who mostly seek to maximize the security of the party-state, national security and economic advancement of the PRC, and in that order.

\footnotetext{
${ }^{75}$ Suisheng Zhao, 'A Revisionist Stakeholder: China and the Post-World War II World Order' Journal of Contemporary China, 27:113 (2018), pp.655-6.
} 
This concept of party-state realism has been developed on the basis of the realities in post-Mao China, but it should not be seen as applicable only to China. It should also be applicable, perhaps with some modifications, to other countries which is a modified Leninist party-state. A notable example is Vietnam. The variant that should work best for Vietnam is likely to be that which prevailed in China before Xi placed party-centric nationalism ahead of instrumentalism as the second most important defining feature. Further research will need to be conducted in Vietnam to assess and verify the applicability of this analytical framework.

\section{Acknowledgement}

The author would like to thank Sam Zhao, the two anonymous reviewers and Charles Parton for sharing their insights on the paper.

\section{Notes on author}

Steve Tsang is Professor of Chinese Studies and Director of the SOAS China Institute, School of Oriental and African Studies University of London, UK. He is also an Emeritus Fellow of St Antony's College, Oxford, and an Associate Fellow of the Chatham House. 